\title{
Editorial
}

\section{The Thought Itself}

Libraries? A place where books are shelved-a place where knowledge is organized and accessed through call numbers, each book allotted a unique position on the shelf, all books equally unique-a place where bibliographic tools are used to find the books.

Bibliographic tools represent our stock-in-trade. The catalog is the primary symbol of our control of books, and it is the intellectual foundation upon which we have chosen to build our profession. This foundation has changed over time, but its basic purpose is unchanged: to allow someone to find a book by a known author, title, or subject-as represented in the Library of Congress Subject Headings List, a taxonomy of knowledge-to know what the library has, and to assist in the choice of a book.

The tools are complicated, and their numbers increase at a confounding rate. Other tools help us to manage this complexity. The bibliographical strata accumulate. We move further and further away from the thought itself and the process of creation.

Instead we deal with artifacts. First, it was the book as artifact. Then the card catalog emerged and represented the collection as artifact. Now other more sophisticated, secondary, bibliographical tools treat the primary bibliographical tools as artifacts. Meanwhile, librarians are cautioned against dealing with knowledge itself, or even the book itself, and are left citing the source-the reference source.

Throughout this long process of development we have lost sight of what is most precious: thought, the creation of the human mind.

\section{And music.}

Finished as no music is ever finished.

Displace one note and there would be diminishment.

Displace one phrase and the structure would fall.

It was clear to me that sound I had heard

in the Archbishop's palace was no accident.

Here again was the very voice of God.

I was staring through the cage

of those meticulous notes

at an absolute beauty.-Amadeus

What creative force could we as librarians exert to represent knowledge in a manner that celebrates its many wonders, mysteries, and beauties? To be able to move beyond the artifact to the original thought-to learn of new marvels and to share these marvels with others-to build an institution that is a testament to life's creative forces, not a storehouse of inert matter, unrepresented.

Vague memories persist of a time, when because of scarcity, a book or a small set of books would be assigned to clerics. They were responsible for protecting and representing their works. Is there any way for us to use our technology, experience, and creativity to reunite our profession with what we have lost? What structures and processes could we develop?

I have many books and other works that I would like to represent, to praise, and to critique. As first in line, I would like to take Tolstoi's War and Peace, Hawthorne's Scarlet Letter, 
de Stendahl's Red and the Black, Mann's Death in Venice, Kuhn's Structure of Scientific Revolutions, Tolkien's Hobbitt, Jefferson's Declaration of Independence, and the movie Amadeus. There are hundreds more.

As an afterthought, I should probably include Frost's The Road Not Taken. CHARLES MARTELL

\section{IN FORTHCOMING ISSUES OF \\ COLLEGE \& RESEARCH LIBRARIES}

Funding Online Services from the Materials Budget

by Jay Martin Poole and Gloriana St. Clair

Reactions to Funding Online Services from the Materials Budget

by Shelia Dowd, John Whaley, and Marcia Pankake

Underground Libraries

by Rolf Fuhlrott

Conversation, A New Paradigm for Librarianship?

by Joan M. Bechtel

A View from the Trenches: Costing and Performance Measures by Charles R. McClure

Organizational Paradigm for Effective Academic Libraries by David W. Lewis

Corporate Annual Reports in Academic Business Libraries by Judith R. Bernstein 